九州大学学術情報リポジトリ

Kyushu University Institutional Repository

Key to families, subfamilies, tribes and genera of the superfamily Curculionoidea of Japan excluding Scolytidae, Platypodidae and Cossoninae : Comparative morphology, phylogeny and systematics of the superfamily Curculionoidea of Japan. III

Morimoto, Katsura

Entomological Laboratory, Department of Agriculture, Kyushu University

https://doi.org/10.5109/22693

出版情報：九州大学大学院農学研究院紀要. 12 (1)，pp.21-66，1962-06. Kyushu University バージョン：

権利関係 : 
Key to families, subfamilies, tribes and genera of the superfamily Curculionoidea of Japan excluding Scolytidae, Platypodidae and Cossoninae

(Comparative morphology, phylogeny and systematics of the superfamily Curculionoidea of Japan. III)

\section{Katsura Morimoto}

In this paper a key to families, subfamilies, tribes and genera of the superfamily Curculionoidea excluding Scolytidae, Platypodidae and Cossoninae is given. Scolytidae and Platypodidae have been studied by Dr. Jozo Murayama and Mr. Akira Nobuchi, and the revision of the subfamily Cossoninae will be published before long by Dr. Masayasu Konishi.

I acknowledge my indebtness to the late Prof. Teiso Esaki, Prof. Keizô Yasumatsu and Prof. Yoshihiro Hirashima for their kind guidance in the course of the present study.

To Prof. Toichi Uchida and Prof. Chihisa Watanabe, of Hokkaido University, I am much indebted to the examination of the type specimens described by Dr. Hiromichi Kôno.

Key to families of Curculionoidea of Japan.

1. Maxillary palpi 4-segmented. Maxillary lacinia distinct. Mandibles and maxillae move in horizontal plane. Penis with the dorsal and ventral plates of the same size. Cap-piece of tegmen not bilobed, large. Antennae always straight. Preoral cavity divided by a transverse wall or narrow bridge (excepting Rhynchitinae). Abdomen with the 3rd-6th sternite similarly articulated to each other, the suture between 6 th and 7 th sternites deeply inflected. Ovary with $4-5$ pairs of ovarioles ..................................2

$1^{\prime}$. Maxillary palpi 3-segmented. Maxillary lacinia very often indistinct. Mandibles move more or Iess obliquely. Penis with the dorsal plate much narrower than the ventral one or the dorsal

Contribution Sęr. 2, No. 138. Entomological Laboratory, Kyushu University. 
plate absent. Cap-piece of tegmen bilobed or vestigial. Antennae often geniculate. Preoral cavity without a transverse wall or bridge. Ovary with $1-2$ pairs of ovarioles .........................

2. Labrum distinct and separated. Preoral cavity completely divided by a transverse wall. Labial and maxillary palpi normal, flexible. Tentorial bridge incomplete, posterior arms reduced to a pair of small processes and originated from postoccipital suture. Elytral epipleura invisible from sides. Testis with 1.2 pairs of accessory glands. Ovipositor with styli strongly sclerotized and toothed, coxites deeply inflected inwards from above. Female with 9th abdominal tergite Anthribidae

$2^{\prime}$. Labrum indistinguishable. Labial and maxillary palpi rigid, inflexible. Preoral cavity with a transverse bridge connecting the pregenal areas (Attelabinae) or the bridge absent (Rhynchitinae). Tentorium with the posterior arms broad, originated from the gular suture and ventral parts of postoccipital suture. Elytral epipleura freely visible from sides. Testis with 3 or more paired accessory glands. Ovipositor normal or vestigial.........Attelabidac

3. Postcoila shallow, located on the anterior margin of postgenal area, into which the ball of postartis of mandible fits not strongly. Maxillae move nearly in horizontal plane. Head never produced into a rostrum or with a very short rostrum. Tentorium with the posterior arm very broad, originated from postoccipital, gular and hypostomal sutures. Ovipositor vestigial .....................4

$3{ }^{\prime}$. Postcoila deep, located on the postgenal arm a little behind the anterior margin, into which the ball of postartis of mandible fits strongly. Maxillae move vertically. Head more or less produced into a rostrum. Tentorium with the posterior arms originated from postoccipital and gular sutures. Ovipositor always present

4. Anterior tarsi with the 1st segment longer than the 3 followings taken together. Abdomen with the 3rd-7th segments freely articulated to each other, 9th sternite absent in male. Penis without apophysis. Maxillary lacinia distinct ...................Platypodidae

4'. Tarsi with 1 st segment shorter than the 3 followings taken together. abdomen with the 3rd and 4th sternites connate, 5th--7th segments similarly articulated to each other, 9th sternite present in malc. Penis with a pair of apophysis. Maxillary lacinia indistinct ...... Scolytidae

5. Prementum normal, freely visible from ventral side. Antennae with club segmented, closely pubescent. Penis with the ventral plate not incised. Posterior part of ventriculus furnished with several gastric caecae. Pygidium formed of 8 th tergite in male 
$5 \prime$. Prementum very small, deeply retracted into the oral cavity and invisible from ventral side. Penis with the ventral plate incised. Ventriculus furnished with short gastric caecae on entire external surface. Antennae with the 1st segment of club glossy, the other segment of club rigid and closely pubescent, funicle $4-6$ segmented. Pygidium formed of 7 th tergite in male ........... Rhynchophoridae

6. Proventriculus not developed, with 8 or 16 rows of setae. Penis with dorsal and ventral plates, cap-piece of tegmen large, bilobed, often articulated to the basal piece, apical part of cap-piece setose Brenthidae

$6^{\prime}$. Proventriculus well developed, with 8 paires of the row of bladelike plates. Penis with the ventral plate only, dorsal plate absent, cap-piece of tegmen less developed, often absent ......Curculionidae

\section{Family Anthribidae}

As many genera of the Anthribidae remain undissected, I can not answer the question of the phylogeny at present. Following key is given as a preliminary step towards a revision of the Anthribidae from Japan.

Key to the subfamilies of the Anthribidae.

1. Antennac inserted on the dorsal surface of rostrum or head ...... Choraginae

1'. Antennac inserted on the lateral surface of rostrum ...Anthribinae

\section{Subfamily Choraginae}

Key to genera.

1. Dorsal prothoracic carina curving forwards to the sides and distant from the base at the sides

$1^{\prime}$. Dorsal prothoracic carina reaching the sides close to the base and there conspicuously angulated and with a distinct Iateral carina

2. Eyes rounded, the upper edges not closer together than the lower

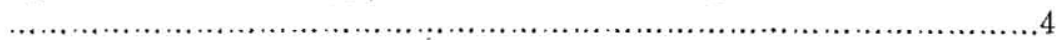

$2^{\prime}$. Eyes elongate-oval, the upper ends closer to each other than the

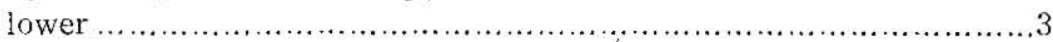

3. Male pygidium with a longitudinal keel, female pygidium with a pair of triangular projections laterally ..............Cilacalus Johraku

$3^{\prime}$. Pygidium simple ......................................... Choragus Kirby

4. First segment of front tarsi longer than the followings taken together. Pygidium nearly as long as wide...Araecerus Schönherr

4'. First segment of front tarsi shorter than the followings taken 
together. Pygidium slender, projected somewhat downwards in a beak-like manner ...................................... Deropygus Sharp

5. Antennae very long, filiform, much longer than body in female and $4-5$ times as long as body in male..............Apolecta Pascoe

5 . Antennae shorter than body. Elytra with humeri a little narrower than pronotum and rounded Notioxenus Wollaston

Subfamily Anthribinae

Key to genera.

1. Dorsal prothoracic carina basal ....................................... 2

$1^{\prime}$. Dorsal prothoracic carina antebasal ..................................8

2. Rostrum strongly carinate on each side and the carinae contiguous with eyes respectively. Rostrum very short, rapidly narrowing

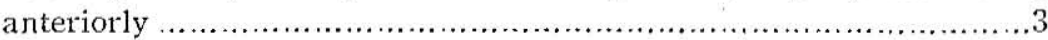

$2^{\prime}$. Rostrum parallel-sided, not carinate on each side ..................4

3. Eyes convex, suboval. Lateral carinae of rostrum reaching the anterior margin of eyes respectively. Frons between eyes neariy as broad as the apex of rostrum.................. Anthribus Forster

3'. Eycs more or less convergent on frons. Lateral carinae of rostrum prolonged posteriorly to the middle of eyes respectively. Frons betwcen eyes narrower than rostrum ...........Paramesus Fahraeus

4. Fourth segment of antennae abnormally large in male. Antennae inserted on the dorso-lateral surface of rostrum. Rostrum extremely short. Antennal scrobes contiguous with eyes. Body

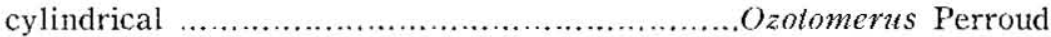

4'. Antennae normal ......................................................

5. Eyes convex, suboval. Postmentum strongly constricted towards the base ..........................................Euparius Schönherr

5'. Eyes emarginate. Postmentum not strongly constricted ..........6

6. Antennal scrobes sulciform, prolonged downards. Antennae short, widened apically from the 4th segment. Body parallel-sided ......

Basitropis Jekel

6'. Antennal scrobes foveiform. Antennae Ionger than body in male, normally clubbed ........................................................

7. Antennae inserted on the dorso-lateral surface of rostrum, antennal scrobes contiguous with eyes. Eyes very strongly emarginate. Rostrum extremely short ............................Phloeobius Schönherr

7 . Antennae inserted on the lateral surface of rostrum, antennal scrobes separated from eyes. Eyes strongly emerginate. Rostrum, as long as wide ................................... Platystomus Schneider

8. Antennal scrobes sulciform, convergent to each other on the ventral surface of rostrum f........................................... 9

8'. Antennal scrobes foveiform, lateral .................................11 
9. Rostrum perpendicular to the axis of body. Dorsal prothoracic carina curving forwards on each side. Lateral prothoracic carina absent. Antennal scrobes shallower ................. Blabirhinus Sharp

$9^{\prime}$. Rostrum oblique to the axis of body. Dorsal prothoracic carina angulate on each side. Lateral prothoracic carina present. Antennal scrobes deeper .............................................10

10. Lateral prothoracic carina prolonged anteriorly from the base to the middle. Dorsal prothoracic carina subparallel to the base of pronotum. Third tarsal segment normal. Body elongate-oval...... Asemorhinus Sharp

$10^{\prime}$. Lateral prothoracic carina developed in entire length of pronotum. Dorsal prothoracic carina curving forwards to the sides. Third tarsal segment small, retracted into the anterior cavity of the 2nd segment. Body parallel-sided ........................ Dendrolrogus Jekel

11. Eyes emarginate. Antennal scrobes lateral or dorso-lateral, partly visible from above.................................................... 12

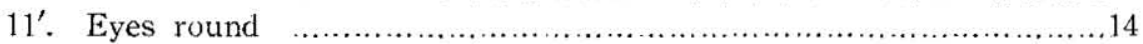

12. Antennae filiform, very slender, $3-4$ times as long as body in male and much longer than body in female. Small species Exillis Pascoe

$12^{\prime}$. Antennae very robust, shorter than body. Large species ........13

13. Pronotum with a horseshore-shaped decp depression Stiboderes Schönherr

13'. Pronotum simple .................................... Xylinades Imhoff

14. Antennal scrobes latero-dorsal. Rostrum suddenly dilated before the middle, with a dcep median Iongitudinal sulcus. Male antennae $2 \approx 3$ times as long as body. Large species

Mecocerus Schönherr

14'. Antennal scrobes latero-ventral, invisible from above .............15

15. Dorsal prothoracic carina close to the posterior margin, bisinuate, each side of the carina very close to the hind angle of pronotum, lateral carina very short. Hind angle of pronotum narrower than $90^{\circ}$. Small species...................................... Uncifer Jordan

15'. Hind angle of pronotum nearly rectangular. Dorsal prothoracic carina more or less remote from the posterior margin ..........16

16. Prothorax strongly narrowed behind dorsal carina so as to leave a deep excision between it and elytra. First segment of front tarsi a little longer than the followings taken together ..........17

16 . Prothorax normally narrowed behind dorsal carina ...............19

17. Each side of male head expanded into a process bearing eye. Female frons between eyes as broad as rostrum

Zygaenodes Pascoe

$17^{\prime}$. Frons between eyes much narrower than rostrum ..................18

18. Elytra without nodules. Tarsi with the 1st segment slender, nearly 
as long as the remaining segments taken together

Rhaphitropis Reitter

$18^{\prime}$. Elytra nodulosus. Tarsi broader, 1st segment a little shorter than the remaining segments taken together

Directarius Jordan, Dissoleucas Jordan

19. Rostrum separated from head by a transverse sulcus on the ventral surface, perpendicular to the axis of body......Tropideres Schönherr

$19^{\prime}$. Rostrum oblique to the axis of body, not separated from head by

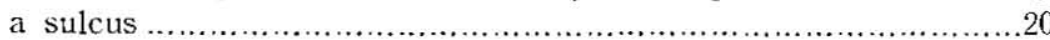

20. Eyes lateral, strongly convex. Frons between eyes a littie narrower than rostrum. Antennal club normal.............. Autotropis Jordan

$20^{\prime}$. Eyes weakly convex, more or less convergent to each other on

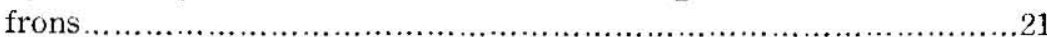

21. Dorsal prothoracic carina curved anteriorly on each side. Antennae with club slender, loosely articulated .................Habrissus Pascoe

$21^{\prime}$. Dorsal prothoracic carina rectangular on each side ...............22

22. Dorsal prothoracic carina close to the base. Antennae with club slender, loosely articulated. Rostrum weakly laminate on each side above antennal scrobe, undersurface simple ...Hypseus Pascoe

$22^{\prime}$. Dorsal prothoracic carina remote from the base. Rostrum strongly laminate on each side above antennal scrobe, with a pair of foveae near the lower end of antennal scrobe. Antennae with club normal. Ulorhinus Sharp

\section{Family Attelabidae}

Family Attelabidae was divided by many authorities such as Voss, Ter-Minasyan, Kôno, etc., into three subfamilies, Attelabinae, Apoderinae and Rhynchitinae. I came to the similar conclusion that it may be better to divide the Attelabidae into two subfamilies, Attelabinae and Rhynchitinae from the point of comparative morphology as already be pointed out by Crowson. Apoderinae auct. and Attelabinae auct. are very close to each other in many characters excepting the constricted head and the shape of tentorium. Euopsini is a distinct tribe and separable from Apoderini and Attelabini by the large eyes and absence of labial palpi. Attelabini should be inferred the most primitive tribe among Attelabinae from the structures of prementum. Apoderini (Apoderinae of many authors) is very uniform in various characters. Subtribe Eugnamptina was treated by Voss under the tribe Rhynchitini and Ter-Minasyan transfered it into the tribe Deporaini. I agree with the treatment of Ter-Minasyan as noted in the following key.

The relationship of the tribes of Attelabidae may be illustrated as follows: 


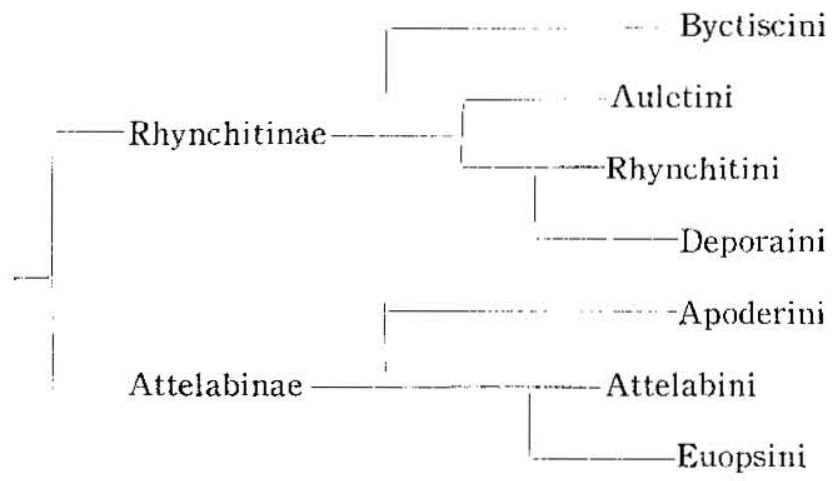

Key to subfamilies.

1. Tibiae mucronate in both sexes, uncinate in male, front tibiae serrate on the ventral margin. Claws connate. Mandibles short, pincer-shaped. Abdomen with the 1 st- 4 th visible sternites conglutinate together, 1st- 6 th tergites conglutinate together. Female genital segment (8th sternite) without an apophysis in general. Labial palpi inserted into cavities on the ventral surface of prementum, 2- or one-segmented or often palpi absent. Ovipositor not developed, styli always absent, coxites small or absent gonopore not opening between coxites. Lateral arms of metendosternite rounded and flat. Preoral cavity divided by a transverse bridge Attelabinae

$1^{\prime}$. Tibiae neither uncinate no rmucronate, not serrate on the ventral margin. Claws free. Mandibles flat, toothed on the inner and outer sides. Abdomen with 1st and 2nd visible sternites fused, the remaining sternites and tergites freely articulated. Female genital segment (8th sternite) always with an apophysis. Labial palpi inserted into the anterior margin of prementum, 3- or rarely 2segmented, postmentum protruding anteriorly on each side. Ovipositor developed, gonopore opening between coxites. Lateral arms of metendosternite more or less pointed and trough-shaped. Preoral cavity without a transverse bridge Rhynchitinae

\section{Subfamily Attelabinae \\ Key to tribes.}

1. Hearl with temples very long, strongly constricted at the base. Elytra without scutellar striae. Posterior arms of tentorium originated from the gular suture, posterior tentorial pits far apart from the postocciput. Prementum with a pair of projections near the anterior margin. Labial palpi one-segmented Apoderini 
1'. Head with temples shorter, not constricted behind eyes. Each elytra with a scutellar stria. Posterior arms of tentorium arisen from gular and postoccipital sutures ...................................2

2. Eyes strongly approximated on frons. Anterior margin of prementum notched twice and sharply toothed thrice. Labial palpi absent .......................................................... Euopsini

$2^{\prime}$. Eyes lateral, broadly separated. Anterior margin of prementum simple. Labial palpi two- or one-segmented Attelabini

\section{Tribe Apoderini}

Key to subtribes and genera.

1. Head short, strongly constricted at the base. Elytra with humeri more or less pointed outwards ......Subtribe Hoplapoderina ........2

1'. Head longer, moderately narrowed from eyes towards the neck. Elytra with humeri rounded ......................................4

2. Elytron with at least 3 costae, striae not weakened posteriorly ...3

$2^{\prime}$. Elytron with a lateral costa, with a conical median knob, striae shallowed behind ...................................Phymatapoderus Voss

3. Abdominal lobe absent. Elytron with at least 5 spurs or knobs Hoplapoderus Jekel

3'. Abdominal lobe present. Elytron with at most 4 spurs or knobs. Paroplapoderus Voss

4. Male head without a neck region ........ Subtribe Apoderina Apoderus Olivier

4'. Male head with a long neck region. ... Subtribe Trachelophorina

5. Abdominal lobe absent. Male head with a distinct neck region Cycnotrachelus Voss

5'. Abdominal lobes present ............................................ 6

6. Each of 2nd - 6th funicular segments of male antennae suddenly swollen at the apex. Male head with a long neck-region

Paratrachelophorus Voss

6'. Funicular segments each gradually widened towards the apex ...7

7. Male head with a short neck-region. Terminal segment of antennae spiniform ....................................Paracentrocorynus Voss

7 . Male head with a longer neck-region. Terminal segment of antennae not slender ...............................Paracycnotrachelus Voss

\section{Tribe Euopsini}

Unique genus Euops Schönherr 


\section{Tribe Attelabini}

Key to genera.

1. Elytra with the bases strongly produced anteriorly beside scutellum. Eyes less convex ........................................Phialodes Roelofs

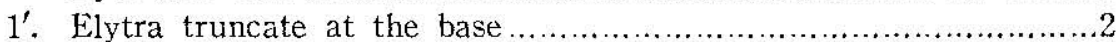

2. Derm closely with hairs ...............................Himatolabus Jekel

$2^{\prime}$. Derm naked .........................................................

3. Antennal club oval, distinctly separable from funicle. Derm reddish ................................................Henicolabus Voss

$3^{\prime}$. Antennal club slender, indistinguishable from funicle in general. Derm steelblue Isolabus Voss

\section{Subfamily Rhynchitinae}

Key to tribes.

1. Elytra almost conjointly rounded at the apex, more or less irregularly punctured, gently inflected at the basal cxtremity. Pygidium almost concealed. Tibiae subcylindrical, not costate on the dorsal margin. Ovipositor with styli absent, coxite simple. Tergite of abdomen without lateral sclerites, spiracles on membrane. Auletini

$1^{\prime}$. Elytra rounded at the apex, more or less regularly punctured striate. Tibiae with the dorsal margin often costate. Pygidium exposed

2. Metacoxae separated from metepisterna by abdominal lobes. Pygidium entirely exposed. Abdominal sternite and pygidium costate along the margin of elytra in repose. Elytra inflected perpendicularly at the basal extremity. Rostrum rather robust. Male prothorax adorned with a spur on each side. Tibiae less strongly costate on the dorsal margin or not costate. Ovipositor with styli absent, coxites simple. Tergite of abdomen with lateral sclerites

Byctiscini

2'. Metacoxae reaching metepisterna, abdominal lobes absent. Dorsal costa of tibiae distinct in general, often finely serrate ..............3

3. Head strongly constricted behind eyes. Elytra slightly inflected at the basal extremity. Rostrum more or less flattened and widened towards the apex ................................... Deporaini

3'. Head rarely constricted behind eyes. Elytra inflected perpendicularly at the basal extremity. Rostrum slenderer. Pygidium partly exposed. Ovipositor with styli absent. Tergite of abdomen with lateral sclerites Rhynchitini

Tribe Auletini Auletobius Desbrochers 


\section{Tribe Byctiscini}

\section{Key to genera.}

1. Tibiae not costate. Scutellum more than three times as broad as long..............................................Aspidobyctiscus Schilsky

$1^{\prime}$. 'Tibiae costate on the dorsal margin. Scutellum at most twice as broad as long Byctiscus Thomson

\section{Tribe Deporaini}

Key to subtribes and genera.

1. Each elytron with a scutellar stria

$1^{\prime}$. Elytra without scutellar striae. Rostrum longer than wide. Antennal club normai. Pygidium and a part of 6 th tergite exposed. Ovipositor with styli, coxite subdivided into dorsal and ventral piece. Abdominal tergite with lateral sclerites......Subtribe Deporaina.....4

2. Rostrum short, robust, as long as wide. Pygidium and a part of 6th tergite exposed. Antennae robust, club oblong oval. Eyes similar in both sexes in size. Ovipositor with styli absent, coxite undivided. Abdominal tergite with lateral sclerites

..Subtribe Chonostropheina nov. Chonostropheus Prell

2'. Rostrum longer. Antennae slender, club loosely segmented. Pygidium exposed. Male eyes much larger than those of female. Abdominal tergite without lateral sclerites, spiracles lying on membrane. Ovipositor with developed styli

Subtribe Eugnamptina

3. Head slightly constricted behind eyes. Tibiae widened from the base towards the apex. Larger species ........... Aderorhinus Sharp

$3^{\prime}$. Head strongly constricted behind eyes. Front tibiae parallel-sided. Eugnamptus Schönherr

4. Pygidium and parts of 5th and 6th tergites of abdomen exposed Deporaus Leach

4'. Pygidium and a part of 6 th tergite exposed ........................5

5. Pronotum slightly rounded at the sides. Body slender. Elytra punctured from the bases to the apices in the same strength ...... Depasophilus Voss

5'. Pronotum strongly rounded at the side. Body subpyriform........6

6. Eyes strongly prominent forwards. Male rostrum short and bearing a pair of tongue-shaped projections below the antennal insertion. Female rostrum relatively longer, without a basal hair tuft

Paradeporaus Kôno

6'. Eyes prominent laterally. Female rostrum with a hair tuft at the base. Male rostrum rather long, without projection below the antennal insertion Chokkirius Kôno 


\section{Tribe Rhynchitini}

Key to genera.

1. Each elytron with a scutellar stria .2

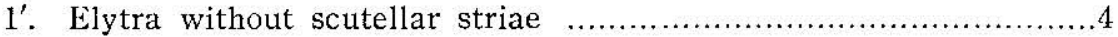

2. Rostrum rather short, straight. Head more or less constricted behind eyes.....................................Lasiorrhynchites Lacordaire

$2^{\prime}$. Rostrum slender, more or less curved. Head not constricted behind eyes

3. Tibiae indistinctly costate. Body slenderer

Pselaphorrhynchites Schilsky

3 '. 'Tibiae distinctly costate on the dorsal margin, the costa finely serrate Merhynchites Sharp

4. Rostrum very slender. Antennae slender, club loosely segmented, each segment of club much longer than wide. Male prothorax adorned with a spur on each side. Derm mottled with recumbent hairs and clothed further with long erect setae

Mechoris Billberg

$4^{\prime}$. Each segment of antennal club not longer than wide. Rostrum and antennac less slenderer .5

5. Male prothorax armed with a spur on each side. Terminal segment of tarsi much longer than the 1st. Elytra with punctures not deeply striate

Rhynchites Schneider

$5^{\prime}$. Malc prothorax unarmed. Terminal segment of tarsi at most slightly longer than the 1st. Elytra punctured striate

Involvulus Seidlitz

\section{Family Brenthidae}

In 1955 Crowson established a family Apionidae including Apioninae, Nanophyinae, Eurhynchinae (including Cylas) and Ithycerinae. Cyladinae may be separable from the Eurhynchinae by the position and number of the segment of labial palpi. As already be noted, Cyladinac has a close relation to Brenthidae auct. than to Apionidae auct. in the structures of labium and prothorax. Brenthidae auct. is very conspicuous in the straight and not or slightly clubbed antennae. The other characters studied are, however, similar to Cylas and Apion. From these points it may be better to combine the Brenthidae and Apionidae into a family.

Desmidophorus has been treated under the subtribe Ithyporina of the subfamily Cryptorrhynchinae basing on the sulcate prosternum and the general shape of body, but differs from the subfamily by the mandibles bearing a deciduous cusp, dentate tibiae on the external margin, developed and closely haired corbel of tibiae, Brenthid-Apionid-typed 
aedeagus and proventriculus. From these point I would like to transfer the Desmidophorus from the Cryptorrhynchinae to Brenthidae of new sense tentatively untill the larvae become clear.

The relationship of the subfamilies of Brenthidac could be illustrated as follows.

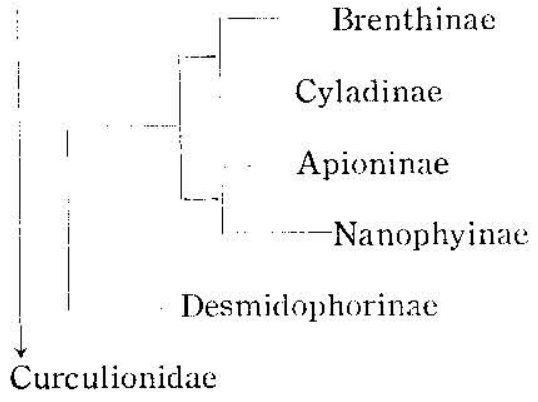

Key to subfamilies.

1. Trochanters large, femora attached to their apex. Small species, not over $4.5 \mathrm{~mm}$. Antennal club compact ..........................2

$1^{\prime}$. Trochanters small, triangular. Larger species .......................3

2. Antennae not geniculate. Labial palpi one-segmented. Body pearshaped, broadest at or behind the middle of elytra. Tarsal claws separated......................................................Apioninae

$2^{\prime}$. Antennac geniculate. Labial palpi 2-segmented. Body oval, broadest at the shoulders. Tarsal claws connate..............Nanophyinae

3. Pygidium concealed, not striate. Visible segment of abdomen not entirely flat. Rostrum longer than wide ..............................4

3 '. Pygidium exposed, with a longitudinal median stria. Visible segments of abdomen flat. Claws separated, bifide. Rostrum a little longer than wide, subquadrate in cross-section. Antennae straight. Front coxac contiguous. Labial palpi 3 segmented ...(Ithycerinae)

4. Antennae geniculate. Front coxae separated. Prosternum before coxae deeply canaliculate. Mandible with a deciduous cusp, leaving a scar. Body oval, closely covered with scales. Labial palpi 3-segmented.............................Desmidophorinae, subfam. nov.

4'. Antennae straight. Prosternum flat. Mandible normal. Prothorax constricted near the posterior margin. Body slender, glossy. Labial palpi inserted into deep pits ........................................5

5. Front coxae contiguous. Mesepimera concealed under elytra. Claws connate at the base .................................... Cyladinae

5'. Front coxae separated. Mesepimera exposed. Claws separated ... Brenthinae 


\section{Subfamily Brenthinae}

Key to tribes.

1. Prothorax more or less compressed a little behind the anterior margin. Rostrum short, small, not sexually dimorphic

$1^{\prime}$. Prothorax not compressed a little behind the anterior margin ...2

2. Inside of front tibiae strongly unidentate ..............Stereodermini

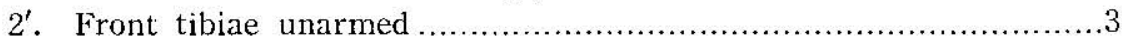

3. Smaller species, rarely over $10 \mathrm{~mm}$ in legth, femora unarmed in general....................................................... Trachelizini

$3^{\prime}$. Larger species; femora dentate in general. Male antennae inserted into the middle of rostrum. Elytra dark-coloured with yellowish spots Arrhenodini

\section{Tribe Calodromini}

Key to genera.

1. Hind tibiae much shorter than tarsi, hind femora much exceeding posteriorly behind the apex of elytra; antennae inserted on the latero-ventral surface of rostrum....................... yphagogus Parry

$1^{\prime}$. Hind legs normal; antennae inserted on the latero-dorsal surface of rostrum

2. Underside of metarostrum semicircularly depressed Sparganophasma Kleine

2 . Underside of rostrum not depressed. Second interval of elytron not separated Asaphopterum Kleine

\section{Tribe Stereodermini}

Key to genera.

1. Antennae slender and long, often longer than body; head more or less sulcate; underside of rostrum with a row of small depressions on each side, inside of the depression velvety

Jonthocerus Lacordaire

$1^{\prime}$. Antennac shorter and robuster, not clubbed; front tibiae distinctly dentate. Cerobales Schönherr

\section{Tribe Trachelizini \\ Key to genera.}

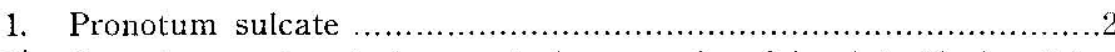

1'. Pronotum not sulcate; posterior margin of head toothed; elytra normally punctured striate Miolispa Pascoe

2. Each elytron with 2 costate intervals........IIypotrachelizus Kleine

2 '. Elytra normally punctured striate; front femora armed each with a small tooth Higonius Lewis 


\section{Tribe Arrhenodini}

Key to genera.

1. Male rostrum as broad as head, short, robust, female prorostrum cylindrical, straight Baryrhynchus Lacordaire

1'. Male rostrum similar to that of female, much narrower than head, slender Pseudorychodes Senna

\section{Subfamily Cyladinae}

Cylas Latreille

\section{Subfamily Apioninae}

Apicn Horbst

\section{Subfamily Nanophyinae}

Nanophyes Schönherr

\section{Subfamily Desmidophorinae}

Desmidophorus Schïnherr

\section{Family Curculionidae}

Curculionidae was divided into two major groups, Curculionidae adelognathi and Curculionidae phanerognathi by Lacordaire, 1863, Marshall, 1916, Reitter, 1916, etc. basing on the structures of mouth organs and the length of rostrum. Leconte and Horn, 1876, divided the Curculionidae into "Byrsopidae, Otiorrhynchidae and Curculionidae". In 1939 van Emden pointed out that Curculionidae could fundamentally be separable into two major groups on larval characters.

In the course of the present study I made an effort to find oul the relationship of the subfamilies from the comparative morphology of adult. Following subfamilies could be said primitive from the structures of adult :

Sitoninae: Maxillary lacinia and galea separated, while the other subfamilies they are connate and forming mola. This subfamily may also be separable from the adelognathous Curculionidae by the short or vestigial ovipositor and normal mandibles.

Hyperinae: IIyperinae auct. and Notarinae auct. can not be separable by adult. Aedeagus of Notaris is of a Brenthid-type.

Ceuthorrhynchinae, Barinae, Magdalinae, some Cryptorrhynchinae: $\mathrm{Ab}$ dominal spiracles on sclerites.

Mecyslobinae: Abdominal spiracles on sclerites, proventriculus less developed. 
From the larval characters, Rhynchaenus, Rhamphus, Mecinus and Orobitis were classified into primitive groups by van Emden.

Cleoninae is greatly different from the other phanerognathous Curculionidae in the position and number of the segments of labial palpi and penis,

Carciliinae, Pissodinae, Styanacinae, Cryptorrhynchinae, Acicneminae, Magdalinae, Hylobiinac and Cossoninae are close to each other. Carcilinae has often been treated under Magdalinae, but the basis of elytra are not produced anteriorly, front coxae are separated and prosternum is canaliculate. Styanax was placed by Heller and Marshall in Hylobiinae, but the apices of tibiae are close to those of Pissodinae than to Hylobiinae. Protacalles and Protacallimus (both Cryptorrhynchinae), Seleucha (Hylobiinae) and Cotasteromimus (Pissodinae) are fairly close (t) each other. Cossoninae may be characterized by the inner setose fringe of tarsal groove of front tibia.

Posterior margins of 2 nd -4 th visible sternites of abdomen are curved posteriorly in the subfamilies Zygopinae, Ceuthorrhynchinae, Barinae, Tychinae and Rhynchaeninae, this character corresponds with the articulating mechanism of sternites.

The general body form of Cioninae is often very close to some genera of Hyperinae such as Phaenopholus. Notarinae and Hyperinae have been treated as distinct subfamilies, but the long-nosed Hyperinae is very close to Notarinae auct. in various characters and I would like to combine these two subfamilies into a subfamily Hyperinae.

It may be better to separate the Rhynchaeninae from Tychiinae by the larval characters. Rhynchaenine larvae are pupate in the tunnel of leaf and the leaf miners of Tychinae are pupate in the soil (Ochyromera, Elleschus, etc.)

Subdivision of Curculionidae adelognathi into subfamilies can be said "artifitial" at present, because they are very often characterized by a single structure, for instance, Eremninae has been characterized only by the presence of the ocular lobes on prothorax, Cyphicerini of Eremininae is apparentiy a part of Ptochini from the point of comparative morphology and not close to Callirhopalini of the same subfamily. Brachyderinae and Otiorrhynchinae can be separable only by the position of the antennal scrobes. When the other characters are taken into consideration, Episomini of Otiorrhynchinac is apparently close to Cneorrhinini of Brachyderinae in the metendosternite, ovipositor and tibiae.

In this paper I would like to propose a new system of Curculionidae adelognathi from the structures of metendosternite, ovipositor and the other characters as follows: 

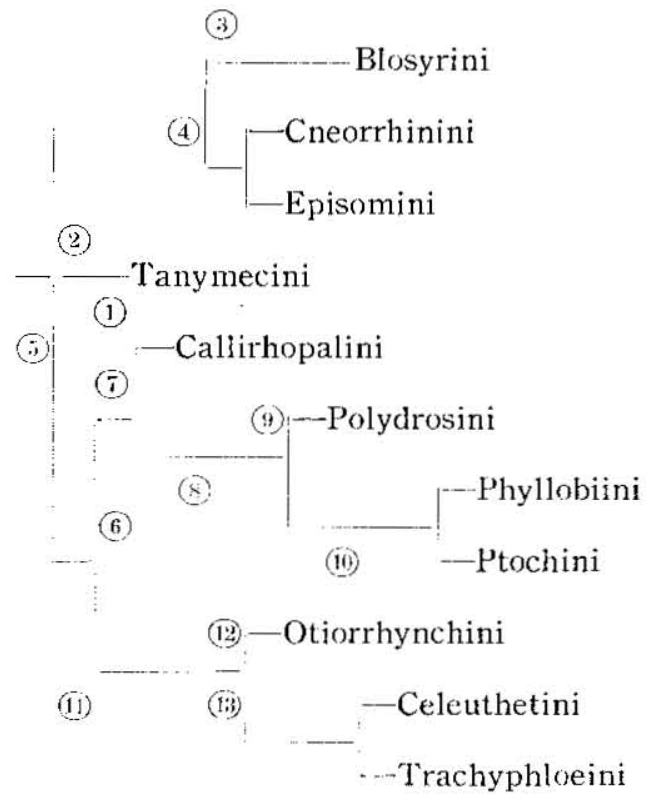

1. Metendosternite Y-shaped or with lateral arms. Pronotum with vibrissae.

2. Metendosternite with lateral arms.

3. Ovipositor with coxite entirely subdivided. Hind tibiae with corbel open.

4. Ovipositur with coxite incised. Hind tibiae with corbel enclosed.

5. Metendosternite Y-shaped, without lateral arm.

6. Anterior margin of metendosternite inflected.

7. Ovipositor with coxite incised. Prementum entirely covers the preoral cavity.

8. Ovipositor developed, divided into two parts, basal part very often membraneous. Prementum not completely covers the preoral cavity.

9. Ovipositor with styli present.

10. Ovipositor with styli absent.

11. Anterior margin of metendosternite not inflected.

12. Ovipositor less developed, coxite simple or incised.

13. Ovipositor developed, basal major part membraneous, terminal sclerites subdivided into two parts by a longitudinal membrane.

The relationship of the subfamilies of Curculionidae could be illustrated as follows: 


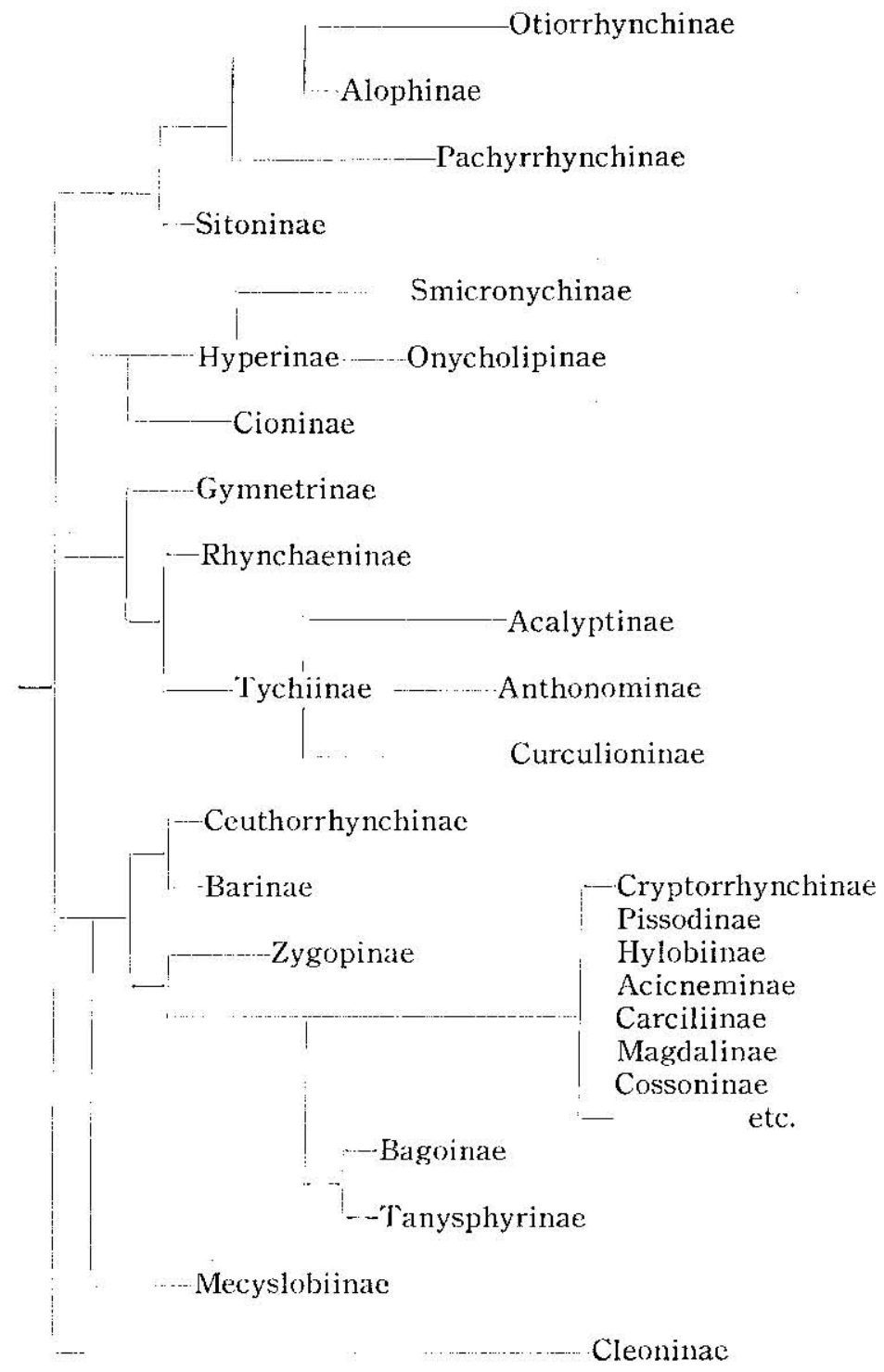

Key to subfamilies.

1. Antennae with funicle 5-segmented. Tibiae mucronate or unarmed.

$1^{\prime}$. Antennae with funicle 6 - or 7 -segmented ............................

2. Metepimera exposed. Frons between eyes narrower than the base of rostrum. Posterior margins of 2-4 visible segments of abdomen 
curved posteriorly at the side. Pygidium concealed........ Cioninae

2'. Metepimera concealed. Frons between eyes as broad as or broader than the base of rostrum. Posterior margins of $2-4$ visible segments of abdomen straight. Pygidium exposed......Gymnetrinae

3. Tarsi 3-segmented, 4th, 5th segments and claws absent. Posterior margins of 2-4 visible segments of abdomen curved posteriorly at the sides. Procoxae contiguous. Metepimera concealed. Each tibia armed with an uncus.................................... Anoplinae

3'. Tarsi 5-segmented; 1th segment small and often invisible ........4

4. Mesepimera strongly ascended upwards between the base of pronotum and elytra, therefore they are visible from above. Hind tibiae unarmed or each with a mucro. Front coxae separated. Posterior margins of 2-4 visible segments of abdomen curved posteriorly at the sides. Eyes lateral....

4'. Mesepimera not ascended; or if ascended, tibiae each armed with an uncus and eyes strongly approximated dorsally ..................6

5. Metasternum contiguous with the 1st segment of abdomen between hind coxae and metepisterna. Metepisterna parallel-sided. Tibiac unarmed or each with a small mucro. Corbel of tibiae opened. Claws often appendiculate. Pronotum with ocular Jobes. Small, oval and convex species............................euthorrhynchinae

5'. Metasternum separated from 1st segment of abdomen on each side, hind coxae contiguous with metepisterna. Metepisterna widened from the middle towards the posterior ends. Tibiae mucronate, corbel with the inner bare carina developed. Claws simple. Body oval, elongate or parallel-sided ..........................Barinae

6. Hind femora much thicker than the antcriors. Hind tibia with the corbel lying entirely on the dorsal edge, unarmed. Mesepimera not ascended upwards. Eyes large, strongly prominent or confluent on frons. Posterior margins of 2-4 visible segments of abdomen curved posteriorly at the sides. Claws separated, appendiculate. Rhynchaeninae

6 . Hind femora not thicker than the anteriors, corbels of tibiae oblique, tibiae truncate or armed at the apcx .......................

7. Eyes large, flat, closely approximated to each other on frons, occupying the major part of frons. Posterior margins of $2 * 4$ visible segments of abdomen curved posteriorly at the sides. Tibiae uncinate. Metepimera often ascended upwards ...........Zygopinae

7 . Eyes not closely approximated on frons; if approximated, metepimera not ascending upwards or posterior margins of abdominal segments straight

.8

8. Mandibular motion vertical. Rostrum very slender. Claws appendiculate, posterior margin of 2 nd visible segment of abdomen curved posteriorly at the sides. Eyes not prominent from the outline of 
head Curculioninae

8'. Mandibular motion horizontal 9

9. Posterior margins of $2-4$ visible segments of abdomen curved posteriorly at the sides. Front coxae contiguous. Claws separated, appendiculate. Rostrum rather robust, nearly as long as head and pronotum taken together. Antennae inserted before the middle of rostrum. Rostrum perpendicular to the axis of body in repose. Smaller species.............................................. Tychiinae

9'. Posterior margins of $2-4$ visible segments of abdomen straight; if curved, front coxae separated or claws simple ..................10

10. Tibiae mucronate or unarmed, the outer setose fringe of corbel forming a transverse apical border to the tibia, though it is often continued round the external angle and along the dorsal edge, forming a strong curve, which is usually subrectangular ........11

$10^{\prime}$. Tibiae uncinate, inner carina of corbel developed, uncus arisen from this carina. The outer setose fringe of corbel oblique and straight or gently curved, or the fringe vestigial ...................20

11. Mandibles with a deciduous cusp, leaving a scar. Rostrum short. Prementum not pedunculate ............................ Otiorrhynchinae

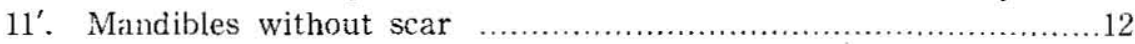

12. Mesepimera very narrow. Elytra contigucus with mesepisterna. Procoxae separated. Rostrum very short. Claws simple, free. Corbels opened. Postmentum not pedunculate ...Pachyrrhynchinae

12 '. Elytra separated from mesepisterna. Procoxae contiguous, or if separated rostrum slender ......................................13

13. Exterior surface of mandibles with scales and hairs. Rostrum short, broader than long. Postmentum not pedunculate. Ovipositor less developed or vestigial. Maxillae with lacinia distinct.

Sitoninae

$13^{\prime}$. Exterior surface of mandibles at most with several hairs. Rustrum longer than wide. Postmentum pedunculate.......................14

14. Procoxae separated. Rostrum slender. Anterior margins of prosternum nearly straight. Front coxae lying on the posterior $1 / 3$ of prosternum. Metepimera concealed..............................15

$14^{\prime}$. Procoxae contiguous, lying about the middle of prosternum ......16

15. Eyes convex. Lateral margins of pronotum costate. Claws simple Petalochilinae

15'. Eyes flat. Lateral margins of pronotum not costate. Claws appendiculate. Pygidium exposed ..........................Acalyptinae

16. Median and hind tarsi not spongy beneath, 3rd segment of front tarsi with long hairs beneath. Front claws much thicker than the posteriors. Median and hind corbels semienclosed. Outer apical edge of front tibiae strongly protruded. Rostrum robust, shorter than pronotum, dorsal surface nearly flat. Antennae in- 
serted near the apex of rostrum, 6-segmented. Ventral longitudinal flange of metendosternite connate with a median longitudinal line of metasternum in entire length........................ Onycholipinae

16'. All tarsi spongy beneath. All claws similar to each other. Outer apical edge of front tibiae simply rounded. Metendosternite normal................................................................. 17

17. Outer surface of mandible strongly compressed and blade-like towards the apex, inner surface deeply excavated. Rostrum robust, subquadrate in cross-section. Antennac inserted ncar the apex of rostrum Alophinae

$17^{\prime}$. Outer surface of mandible not compressed, inner surface with 2 or 3 teeth, not excavated .........................................18

18. Eyes lateral. Prosternum not canaliculated. Claws free ........19

18'. Eyes closely approximated beneath to each other. Prosternum with a shallow canal before coxae. Claws connate. Rostrum separated from head by a transverse depression. Posterior margins of 2-4 visible segments of abdomen curved posteriorly at the sides.

Smicronycinae

19. Eyes strongly convex, distinctly prominent from the outline of head. Rostrum cylindrical. Front coxae lying at the middle or a little before the middle of prosternum. Claws often appendiculate Anthonominae

$19^{\prime}$. Eyes not prominent from the outline of head. Front coxae lying on the middle or behind the middle of prosternum. Claws simple. Antennae inserted near the apex of rostrum................ Hyperinae

20. Front coxae separated, with a few exceptions ${ }^{1)}$.....................21

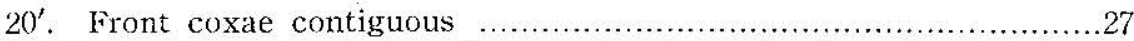

21. Claws bifid, inner branches connate to cach other. Basis of elytra strongly produced anteriorly, covering the basal part of pronotum. Hind angles of pronotum angulate. Front femora much thicker and a little longer than the posteriors Mecyslobinae

$21^{\prime}$. Claws separated. Basis of elytra not laminate in general, basal part of pronotum entirely exposed ............................... 22

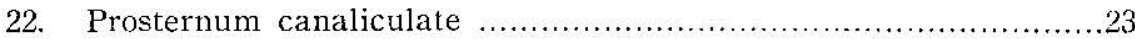

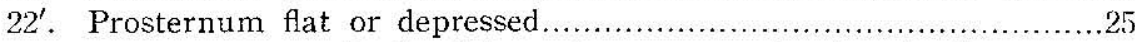

23. Claws simple. Ocular lobes of pronotum developed. Eyes partly covered by ocular lobes in repose ..................................24

$23^{\prime}$. Claws appendiculate, ocular lobes of prothorax absent. Eyes separated from prothorax in repose ........................ arciliinae

1) Some genera of the Ithyporini are close to a certain genus of Lithinini in having the connate front coxae and canaliculate prosternum before coxae, but the formers may be separable from the latter by the slenderer rostrum and antennae which are inserted far behind the apex of rostrum. 
24. Rostrum very short, broader than long, subquadrate in cross-section. Antennae short, scape nearly as long as the first two segments of funicle taken together ...................................... Styanacinae

$24^{\prime}$. Rostrum slender, cylindrical. Antennae slenderer, scape nearly as long as all the segments of funicle taken together

Cryptorrhynchinae

25. Tarsal grooves of front tibiae rounded posteriorly and fringed with setae on the lower part of the margins a little above the lower edge of tibia. Third tarsal segments broader than the 2nd, bilobed

25 . Front tibiae fringed with setae on the lower edge near the apex, tarsal grooves of front tibiae opened behind. Tarsi with the 3rd segment not or a little brodder than the 2nd. Femora unarmed. Body slender, parallel-sided Cossoninae

26. Antennal scrobes oblique, the posterior ends closely approximated or confluent under the base of rostrum. Ocular lobes of pronotum developed. Rostrum longer than pronotum, antennae inserted behind the middle. Abdominal process between hind coxae very broad, broader than coxa ..................................Acicneminae

26'. Antennal scrobes separated throughout. Ocular Iobes of pronotum very weak or absent. Antennae inserted into the middle--apical $1 / 3$ of rostrum .................................................Pissodinae

27. Labial palpi one-segmented or absent. Claws connate.............28

$27^{\prime}$. Labjal palpi 3-segmented. Claws usually separated .................29

28. Labial palpi one-segmented, globular, inserted into a hole at the ventro-lateral edge a little before the middle of prementum. Prementum between palpi transversely depressed. Metepimera exposed. Fifth tarsal segment longer than the 3rd ........Cleoninae

28'. Labial palpi absent. Prementum not divided by a depression. Metepimera concealed. Rostrum robust, as broad as or broader than long, female rostrum swollen. Fifth tarsal segment not longer than the 3rd Galloisiinae

29. Basis of elytra laminate, strongly produced anteriorly and covering the basal part of pronotum .30

$29^{\prime}$. Basis of elytra not produced anteriorly, basal margin of pronotum entirely exposed 31

30. Metepimera concealed, hind angles of pronotum simply rounded. Fifth tarsal segment armed with a pair of laminate projections behind claws. Body rhombic. Trigonocollinae

$30^{\prime}$. Metepimera exposed. Hind angles of pronotum angulate, produced latero-posteriorly. Fifth tarsal segment simple. Body parallel-sided

31. Fifth tarsal segment longer than the 3rd. Anterior margin of prosternum excavated. Ocular lobes often present .32 
31.' Fifth tarsal segment not longer than the 3rd, anterior margin of prosternum not excavated. Ocular lobes absent. Subaquatic species Tanysphyrinae

32. Third tarsal segment much broader than the 2nd, bilobed, 4th segment concealed Hylobiinae

32 . Third segment not or a little broader than the 2nd, not bilobed, 4th segment distinct, exposed. Body closely covered with a dense vernish-like waterproof coating of scales. Subaquatic species

Bagoinate

\section{Sübfamily Cioninae \\ Key to genera.}

1. Tarsus with a single claw

1'. Tarsus with a normal, paired claws, which are connate at the base

2. Front coxae separated. Prosternum before coxae deeply canaliculated Steroonychidius Morimoto

$2^{\prime}$. Front coxae contiguous. Prosternum flat or depressed.

Siereonychus Sulfrian

3. Male tibia mucronate. Elytra without a sutural spot. Anterior margin of prosternum straight or slightly sinuate. Claws of the same length in both sexes Cleopus Stcphens

$3^{\prime}$. Tibiane unarmed in both sexes. Elytra with a sutural spot. Anterior margin of prosternum excavated. Claws of the same length in female, the inner claw shorter than the outer one in male

Cionus Clairville

\section{Subfamily Gymnetrinae}

Key to genera.

1. Front coxae contiguous. Claws connate. Rostrum shorter

Gymnetron Schönherr

1'. Front coxae separated. Claws free. Rostrum longer

Miarus Stephens

\section{Subfamily Anoplinae}

Unique genus Anoplus Schönherr

\section{Subfamily Rhynchaeninae}

Key to tribes.

1. Eyes confluent on frons. Rostrum perpendicular to the axis of body or received upon breast in repose Rhynchaenini

$1^{\prime}$. Eyes lateral, strongly convex. Rostrum directed anteriorly in repose Dinorrhopalini 
Tribe Rhynchaenini

Key to genera.

1. Tibiae unarmed at tip, hind tibiae flattened dorsally in entire length. Rostrum perpendicular to the axis of body in repose......

Orchestoides Roelofs

1'. Anterior four tibiae armed with uncus. Rostrum received on breast in general .......................................................... 2

2. Antennae straight, inserted between eyes .....Rhamphus Clairville

2 '. Antennae geniculate, inserted into rostrum

Rhynchaenus Clairville

\section{Tribe Dinorrhopalini}

Key to genera.

1. Rostrum very short, broader than long. Antennae inserted between eyes. Front coxae separated. Inner apical edge of hind tibia pointed ............................................. Dinorrhopala Pascoe

$1^{\prime}$. Rostrum as long as or longer than wide. Antennae inserted into rostrum. Front coxae contiguous. Inner apical edge of hind tibia rounded Ixalma Pascoe

\section{Subfamily Ceuthorrhynchinae}

Key to tribes.

1. First visible segment of abdomen narrower than the 2nd, subdivided into three parts by coxal cavitics. Rostrum tapered towards the apex. Body globular. Claws bifid, inner branches entirely contiguous to each other .......................................... Orobitini

$1^{\prime}$. First visible segment of abdomen broader than the 2nd, not subdivided. Rostrum parallel-sided ......................................2

2. Hind femora clavate, much thicker than the anteriors. Rostrum a little shorter than pronotum. Claws simple. Eyes partly concealed under pronotum in repose Hypurini

$2 '$. Hind femora not or slightly thicker than the anteriors, or rostrum longer than pronotum if hind femora clavate. Claws often appendiculate .................................................................... 3

3. Elytra with the 8th intervals not broader than the others at the base, humeral tubercles absent, subapical swellings absent. Each interval armed with a row of tubercles. Pronotum without lateral tubercles...........................................................Scleropterini

3 '. Elytra with the 8 th intervals convex, much broader than the others at the base .................................................................... 4

4. Rostrum robust, shorter than pronotum. Eyes entirely exposed or small parts concealed in repose. Ocular lobes absent or weak Rhinoncini 
$4^{\prime}$. Rostrum slender, longer than pronotum. Ocular lobes developed, covering the major parts of eyes in repose.

5. Scutellar lobe of pronotum costate, sharply pointed and strongly produced posterioriy, covering scutellum. Hind femora thicker than the anteriors Mecysmoderini

5'. Scutellum exposed. Posterior margin of pronotum weakly bisinuate. Hind femora not or a little thicker than the anteriors Ceuthorrhynchini

Tribe Orobitini

Unique genus Orobitis Germar

Tribe Hypurini

Unique genus Hypurus Rye

\section{Tribe Scleropterini}

Unique genus Rhytidosomus Schönherr

\section{Tribe Rhinoncini}

Key to genera.

1. Antennal funicle 6-segmented. Prosternum Letween coxae narrow, not canaliculate before coxae Phytobius Schönherr

1'. Antennal funicle 7-segmented. Prosternum between coxae broader, canaliculate before coxes

2. Femora each armed with a small tooth......Rhinoncomimus Wagner

$2^{\prime}$. Femora unarmed Rhinoncus Stephens

\section{Tribe Mecysmoderini}

Unique genus Mecysmoderes Schönherr

\section{Tribe Ceuthorrhynchini}

Key to genera.

1. Antennal funicle 7 -segmented .2

1'. Antennal scape adorned with a very long spine at the apex. Pectoral canal extending into metasternum. Pronotum with a pair of large tubercles at the middle .............................................

2 '. Antennal scape rounded or pointed at the apex ...................4

3. Tibiae flattened, toothed or angulate on the outer side. Pronotum not depressed before scutellum Craponius Leconte

$3 \prime$. Tibiae neither flattened nor toothed. Pronotum deeply depressed before scutellum. Cyphosenus Schultze

4. Intervals of elytra each with a row of pointed tubercles or setigerous granules. Pronotum with a pair of tubercles, basal margin nearly straight 
$4^{\prime}$. Dorsal part of elytra neither tuberculate nor granulate.............7

5. Elytra with a white scutellar spot ...................................6

5'. Elytra without a scutellar spot. Black. Each interval of elytra with a row of pointed tubercles and a row of dark setae. Pronotum convex, glossy. Mesosternum excavated ...........Zacladus Reitter

6. Black. Pronotum strongly punctured. Tibiae simple, femora armed ........................................... Homorosoma Frivaldsky

6'. Antennae, rostrum and legs reddish. Pronotum weakly punctured. Median tibiae with a small hair tuft before the apex. Each interval of elytra clothed with a row of crect white scales. Mesosternum weakly depressed Micrelus Thomson

7. Pectoral canal extending onto metasternum. .8

$7^{\prime}$. Pectoral canal not extending behind front coxae Ceulhorrhynchus Germar

8. Tibiae flattened, not dilated towards the apex. Corbels of hind tibiae ascended anteriorly. Body entirely or partly red

Cocliodes Schönherr

8'. Tibiae not flattened, dilated towards the apex. Corbels not ascended. Body black .......................... Cidnorrhinus Thomson

9. Intervals of elytra each armed with a row of pointed setigerous granules. Pectoral canal extending onto metasternum.

Ceuthorrhynchidius J. du Val

9'. Intervals of elytra unarmed. Pectoral canal not extending behind front coxae Calosirus Thomson

\section{Subfamily Barinae}

Key to genera.

1. Elytron provided with 8 punctured striae, lateral 3 striae not reaching the base, 7 th and 8 th striae confluent above the 2nd segment of abdomen. Rostrum not separated from frons. Prosternum deeply depressed before coxae. Pronotum with ocular lobes. Pygidium exposed. Body rhombic . Centrinopsis Roelofs

1'. Elytron provided with 10 punctured striae, 9th and 10th striae separated throughout ...................................................2

2. Tarsi each with a single claw. Rostrum not separated from frons. Pectoral canal extending to the middle of front coxae. Antennae with funicle widened terminally, continuous to club. Pygidium exposed. Posterior margin of 5 th visible segment of male abdomen quadrately projected posteriorly at the middle, the projection glossy. Body rhomic Barinomorphus Morimoto

$2^{\prime}$. Tarsi each with a normal, paired claws ................................ 3

3. Hind femora exceeding the apex of elytra, hind tibiae very short, shorter than half the length of hind femora, curved. Rostrum 
not separated from frons. Body cylindrical, linear. Elytra each with a fovea near the apex in male, subapical swellings absent Aparallelodemas Morimoto

3'. Hind femora not exceeding the apex of elytra, hind tibiae nearly as Iong as femora. Elytra without fovea............................4

4. Rostrum not separated from frons, shorter than pronotum. Pygidium oblique or horizontal, entirely concealed at least in female. Body elongate, parallel-sided ......................... Limnobaris Bedel

4'. Rostrum separated from frons by a transverse depression, often the depression weak .................................................. 5

5. Prosternum deeply canaliculate, inside of the canal glossy. Body

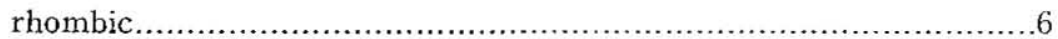

5'. Prosternum not or shallowly canaliculate, inside of the canal not glossy, the canal not reaching front coxae ...........................

6. Pygidium exposed in both sexes. Posterior margin of the 5th visible segment of male abdomen quadrately projected posteriorly at the middle, the projection glossy. Claws connate

Barinomorphoides Morimoto

$6^{\prime}$. Pygidium entirely concealed in both sexes. Claws free. Corbel with the inner canina strongly laminate, dorsal end of the carina angulate Pseudorhyssematus Morimoto

7. Tibiae uncinate and further mucronate, the mucro rectangular to the axis of tibia, inner margin of tibiae serrate. Pronotum broadest at the base. Claws connate. Labial palpi one-segmented Didothis Zaslavsky

7'. Tibiae uncinate, inner margin not serrate. Palpi 3-segmented 8

8. Pygidium concealed. Mesosternum lying on the same level with pro- and metasternum. Scutellum invisible. Keibaris Chưjô

8'. Pygidium exposed. Mesosternum oblique or depressed. Scutellum visible Baris Germar

\section{Subfamily Zygopinae}

\section{Key to tribes.}

1. Prosternum canaliculate, each side of the canal keeled ..............2

$1^{\prime}$. Prosternum flat or depressed ............................................4

2. Scutellar lobe of pronotum developed and covering scutellum ...... Lobotrachelini

2 . Base of pronotum straight, arched or bisinuate ....................3

3. Anterior tibiae more or less depressed, with a fine stria along the lateral margin, which is bordered with fine carinae. Mesepimera strongly ascended upwards between the base of pronotum and elytra, therefore they are clearly visible from above. Small species 
3'. Anterior tibiae not or rarely depressed, simple or with a lateral keel. Mesepimera not ascended upwards. Metepisterna parallelsided

Othippiini

4. Antennae with funicle 6-segmented. Mesepimera not or weakly ascended upwards Mecopini

4'. Antennae with funicle 7 -segmented .5

5. Mesepimera large, strongly ascended upwards between the base of pronotum and elytra, therefore they are clearly visible from above, their upper limits being far higher than that of metepisterna and reaching at least to the level of stria 9 of elytra. Metepisterna parallel-sided, posterior coxae broadly separated from lateral margin of elytra Coryssomerini

5'. Mesepimera smaller, not ascended upwards. Metepisterna tapered posteriorly, posterior coxae being close to lateral margin of elytra. Prosternum before coxae depressed. Rostrum perpendicular to the axis of body in repose Sphadasmini

\section{Tribe Lobotrachelini}

Key to genera.

1. Pectoral canal confined to prosternum, open behind, mesosternum slightly depressed or flat, not grooved ......Lobotrachelus Schönherr

$1^{\prime}$. Pectoral canal prolonged to mesosternum, sharply limited behind. Procoxae comparatively larger and legs shorter.......Metetra Pascoe

\section{Tribe Othippiini}

Egiona Pascoe

\section{Tribe Mecopini}

Key to genera.

1. Antennae with club very long, cylindrical, first segment of club as long as all the segments of funicle taken together.

Neomecopus Hustache

1'. Antennae with club normal, oval or fusiform

2. Posterior femora with a triangular large tooth and the exterior margin of the tooth serrate. Antennae with the 1st segment of club rapidly tapered basally. Posterior tibiae dilated inwards at the middle Mecopomorphus Hustache

2 . Femora with the tooth small and normal, posteriore tibiae parallel-sided. Anterior coxae not contiguous. Prosternum with a pair of long spines in male Phylaitis Pascoe 


\section{Tribe Isorrhynchini}

Key to genera.

1. Scutellum depressed, oblique to the axis of body, posterior margin much lower than the level of elytra. Pronotum with weak ocular lobes. Front femur a little thicker and the tooth larger than the hind ones. Each femur with a pair of setae between the tooth and apex. First segment of abdomen as long as the 2nd and 3rd taken together. Lateral tubercles on pronotum absent. Both sides of prosternal canal sharply keeled and the canal reaching the middle of front coxae....................... Macrotelephae Morimoto

$1^{\prime}$. Scutellum normal, flat or slightly covex. Ocular lobes on pronotum absent ........................................................

2. Front femora much thicker than posterior ones and with a very large tooth, with a pair of long setae between the tooth and apex. Front tibiae with several long erect or suberect setae on the inner margin near the base. Prosternal canal limited by the front coxae, both sides of the canal bordered with obtuse and broaler keels. Pronotum with lateral tubercles... Telephae Pascoe

$2^{\prime}$. Front femora scarcely thicker than posterior ones, the tooth not veryl arge. Front femora and tibiae without special setae .........3

3. Prosternal canal reaching the posterior margin of front coxae, both sides of the canal sharply limited by keels. First segment of abdomen as long as the 2nd and 3rd taken together. Lateral tubercles on pronotum absent........................ Podeschrus Roelofs

$3^{\prime}$. Prosternal canal reaching the anterior margin of middle of front

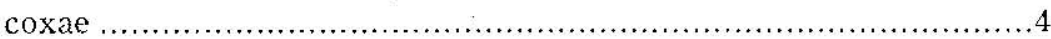

1. Prosternal canal bordered with obtuse and broad kecls, the keel reaching the anterior margin of front coxa. First segment of abdomen as long as the 2nd at the lateral margin. Lateral tubercles on pronotum present Ellatocerus Schönherr

4'. Prosternal canal reaching the middle of front coxae and bordered with sharp keels. First segment of abdomen as long as the 2nd and 3rd taken together. Lateral tubercles on pronotum absent. Kumozo Morimoto

\section{Tribe Coryssomerini}

Key to genera.

1. Elytra with stria 1 not reaching the base, but ceasing behind scutellum. Pygidium almost covered ...............................2

$1^{\prime}$. Elytra with stria 1 reaching the base. Pygidium exposcd. Eyes large, closely subcontiguous. Mesosternal process as broad as coxa Melialma Pascoe 
2. Lower margin of eye lying far above the upper edge of the scrobe..............................................................................

2 . Lower margin of eye on a level with the upper edge of scrobe, eyes sharply acuminate in front. Body subrhombic or elliptic Osphilia Pascoe

3. Body subrhombic or elliptic, pronotum narrower than elytra Euryommatus Roger

$3^{\prime}$. Body oblong, cylindrical, parallel-sided, pronotum scarcely narrower than elytra Heurippa Pascoe

\section{Tribe Sphadasmini}

Nipponosphadasmus Morimoto

\section{Subfamily Curculioninae}

Curculio Linné

\section{Subfamily Tychiinae}

Key to tribes.

1. Angles of second visible segment of abdomen extending to the 4th. Rostrum tapered anteriorly from lateral aspect ...... Tychiini

$1^{\prime}$. Angles of second visible segment of abdomen not extending to the 4 th

2. Ocular lobes of prothorax developed. Rostrum robust. Eyes not prominent from the outline of head. Pronotum strongly covex. Prosternum canaliculate before coxae ..................... Demimaeini

2 . Ocular lobes absent. Eyes more or less prominent from the outline of head. Pronotum flat or weakly convex ..........................

3. Prosternum canaliculate. Pygidium entirely concealed. Rostrum cmbraced on prosternum in repose. Eyes less convex...Elleschini

$3^{\prime}$. Prosternum not canaliculate. Pygidium often exposed. Rostrum perpendicular or anterior to the axis of body in repose. Eyes strongly convex Endaeini

\section{Tribe Tychiini}

Key to genera.

1. Antennae with funicle 7-segmented Tychius Schönherr

$1^{\prime}$. Antennac with funicle 6 -segmented Sibinia Germar

Tribe Demimaeini 


\section{Tribe Elleschini}

Elleschus Stephens

\section{Tribe Endaeini}

\section{Key to genera.}

1. Antennae with funicle 6 -segmented 2

$1^{\prime}$. Antennae with funicle 7-segmented ....................................4

2. Front femora much thicker than the posteriors and each bearing a large tooth Endaeus Schönherr

2 '. Front femora not thicker than the posteriors and each bearing a small or minute tooth .................................................... 3

3. Tibiae uncinate, unci oblique. Antennae with funicle as long as scape .............................................. ryphorhynchus Roelofs

$3^{\prime}$. Tibiae with front and middle pairs very finely uncinate, hind tibiae unarmed. Femora armed each with a minute obtuse tooth. Antennae with funicle much longer than scape

Endaenidius Morimoto

4. Front femora much thicker than the posteriors and bearing a large triangular tooth, with several long setae on the inner margin near the apex

$4^{\prime}$. Front femora not thicker than the posteriors and bearing a small tooth

5. Prosternum marginate with submarginal transverse ditch before coxae. Pronotum broadest about the middle......Eusynnada Heller

5'. Prosternum before coxae not ditched transversely, nearly flat. Rostrum robust .......................................Exochyromera Voss

6. Pronotum broadest at the base. Body black .......................

$6{ }^{\prime}$. Pronotum broadest at the middle. Submarginal transverse ditch of prosternume onnate with coxal groove. Tarsi uncinate. Femoral tooth small Heterendaeus Morimoto

7. Scutellum distinct ..........................Sphinxioides Voss et Châjô

$7^{\prime}$. Scutellum concealed .................................... Sphinxus Roelofs

\section{Subfamily Sitoninae}

Key to genera.

1. Elytra strongly rounded at the sides, humeri absent. Metasternum very short Parasitones Sharp

1'. Elytra with rectangular humeri. Wings functional ..................2

2. Labial palpi three-segmented, attached to the anterior margin of prementum. Mandibles of normal size, shorter than the sinallest diameter of eyes Sitona Germar 
2'. Labial palpi one-segmented, attached to the ventral surface of prementum. Mandibles larger, Ionger than the smallest diameter of eyes

Eugnathus Schönherr

\section{Subfamily Pachyrrhynchinae}

Unique genus

Pachyrrhynchus Germar

\section{Subfamily Otiorrhynchinae}

Key to tribes.

1. Antennal scrobes short, usually located on the dorsal surface of rostrum; or if on sides, directed towards eyes .....................2

1'. Antennal scrobes rather long, located on the sides of rostrum and directed very obliqucly downwards or curved downwards before eyes

2. Corbels of hind tibiae enclosed. Claws connate. Metepisterna aimost concealed. Bases of elytra slightly produced anteriorly ... Episomini

2 . Corbels of hind tibiae opened or semienclosed. Claws connate or free. Basis of elytra not produced anteriorly..........................

3. Procoxac connate. Female 8th sternite with an aphophysis .....4

$3^{\prime}$. Procoxae separated. Epistome ill-defined. Corbels of hind tibiae semienclosed. Female 8th sternite without apophysis

Celeuthetini

4. Mesepisterna very large and in direct contact with the margin of elytra, mesepimera very small. Humeral calosities of elytra absent

Otiorrhynchini

4'. Mesepisterna a little larger than mesepimera and not reaching the margin of elytra ....................................................... 5

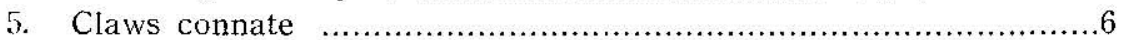

$5^{\prime}$. Claws separated. Prementum covering entire buccal cavity. Postmentum very short or not pedunculate. Epistome well defined...

Ptochini

6. Elytra oval, humeri absent. Pronotum with ocular lobes. Antennal scrobes Iatero-dorsal in position, directing towards eyes, nearly straight. Prementum covering entire buccal cavity. Postmentum not pedunculate. Epistome well defined .................. Callirhopalini

6'. Elytra with rectangular humeri. Prementum shortly pedunculate. Epistome ill-defined. Prothorax without ocular lobes ...Phyllobiini

7. Prothorax with vibrissae ................................... Tanymecini

7 . Prothorax without vibrissae.............................................

8. Corbels of hind tibiae enclosed. Prementum entirely covering the buccal cavity. Hind wings not functional................. Cneorrhinini 
8'. Corbels opened or semienclosed .....................................

9. Elytra with rectangular humeri. Prementum partly covering the buccal cavity. Postmentum shortly pedunculate. Hind wings functional............................................................ Polydrosini

$9^{\prime}$. Elytra oval, humeri reduced. Prementum entirely covering the buccal cavity. Postmentum not pedunculate. Hind wings vestigial Blosyrini

Tribe Episomini

Episomus Schönherr

Tribe Celeuthetini

Arrhaphogaster Roelofs

\section{Tribe Otiorrhynchini}

Key to genera.

1. Rostrum abruptly declivous dorsally at the apex

1'. Rostrum not abruptly declivous dorsally at the apex

Asphalmus Sharp

Omoiotus Sharp

\section{Tribe Phyllobiini}

Phyllobius Germar

\section{Tribe Ptochini}

Key to subtribes and genera.

1. Elytra with humeri reduced, oval. Hind wings not functional ...

Subtribe Ptochina........................ 4

$1^{\prime}$. Elytra with rectangular humeri. Hind wings functional ...........5

2. Anterior margin of pronotum truncate, without ocular lobes......... Subtribe Myllocerina ....................5

$2^{\prime}$. Pronotum with either ocular lobes or vibrissae, or with the both

3.

3'. Rostrum much longer than

3 . Rostrum much longer than wide ............. Subtribe Phytoscaphina Phytoscaphus Schonherr

4. Pronotum with ocular lobes. Eyes larger, oblong-oval. Scutellum minute Calomycterus Roelofs

4'. Pronotum without ocular lobes. Eyes smaller, convex. Scutellum absent. Myosides Roelofs 
5. Basal margin of pronotum straight or slightly rounded, not produced posteriorly towards scutellum. Basis of elytra not produced anteriorly .6

$5^{\prime}$. Basal margin of pronotum visibly bisinuate, more or less produced posteriorly towards scutellum. Basis of elytra slightly produced anteriorly and covering the basal part of pronotum, the covered basal area narrow crescent-shaped and declivous downwards Myllocerus Schönherr

6. Antennal scrobes approximated dorsally, oval, enclosed. Rostrum very short. Scape strongly curved inwards. Eyes large, lateral in position .........................................Hyerstylus Roelofs

$6^{\prime}$. Antennal scrobes not approximated, opened behind ................. 7

7. Antennae slender, longer than the entire length of body. Epistome elongate, its hind margin forming a narrow angle, which extends behind the point of antennal insertion. Prementum with 4 setae. Dorso-lateral carinae of rostrum absent ........Eumyllocerus Sharp

$7^{\prime}$. Antennae less siender, shorter than the length of body Macrocorynus Schönherr

8. Apex of rostrum pointed and horn-shaped. Antennal scrobes approximated. Anosimus Roelofs

8'. Apex of rostrum simple, triangularly or semicircularly notched...9

9. Mentum with a pair of setae. Pronotum truncate or feebly bisinuate at the base. Corbels of hind tibiae semienclosed, having a bare internal carina ............................... cyphicerus Schönherr

9'. Mentum with $4-8$ setae .............................................. 10

10. Epistome short, its posterior margin broadly rounded or forming an obtuse angle, which does not extend behind the point of insertion of antennae. Mandible trisetose .............................11

$10^{\prime}$. Epistome elongate, its posterior margin narrowly rounded, which is exceeding slightly behind the point of insertion of antennae. Rostrum parallel-sided. Mandible multisetose. Basal margin of pronotum bisinuate. Eyes dorso-lateral in position

Canoixus Roelofs

11. Postocular lobes of prothorax well developed. Dorsal area of rostrum at the base narrower than frons

Cyphicerinus Marshall

$11^{\prime}$. Postocular lobes obsolete and replaced by vibrissae, pronotum truncate or slightly bisinuate at the base ............................12

12. Frons tumid, as wide as the greatest distance between scrobes, with a bare space behind epistome .............. Oedophyrus Marshail

12'. Frons not tumid, narrower than the greatest distance between scrobes, without a bare space .................Cyrtepistomus Marshall 


\section{Tribe Callithopalini}

Callirhopalus Hochhuth

\section{Tribe Tanymecini}

Key to subtribes and genera.

1. Claws free

Subtribe Piazomiina

Sympiezomias Faust

1'. Claws connate

2. Rostrum separated from frons by a transverse furrow or depression. Subtribe Prypnina.

$2^{\prime}$. Rostrum not separated from frons by a furrow or depression Subtribe Tanymecina.

3. Corbels of hind tibiae semienclosed. Declivity of elytra with erect or recumbent hairy scales, which are hardly longer than those on disc. Hind tibiae among the recumbent scales with erect, rather short hairy scales; on the dorsal surface of hind tibiae these are not longer than on the other tibiae Amystax Roelofs

3 '. Corbels opened. Declivity of elytra with very long erect bristles. Hind tibiae with very long rough hairs

4. Elytra with rectangular humeri Enaptorrhinus Waterhouse

4'. Elytra with humeri absent Chlorophanus Germar

5. Mandibles normal, scar distinct. Scepticus Roelofs

5 . Outer surface of mandibles strongly compressed and blade-like towards the apex, scar not recognizable......Meotiorrhynchus Sharp

\section{Tribe Cneorrhinini}

Key to genera.

1. Prothorax strongly bisinuate at the base, bases of elytra slightly produced anteriorly Dermatoxenus Marshall

1'. Prothorax truncate or slightly rounded at the base, bases of elytra not produced anteriorly Catapionus Schönherr

Tribe Polydrosini

Scythropus Schönherr

Tribe Blosyrini

Blosyrus Schönherr

\section{Subfamily Petalochilinae}

Tribe Derelomini 
Subfamily Acalyptinae

Acalyptus Schönherr

Subfamily Onycholipinae

Isonycholips Chûjô et Vose

\section{Subfamily Alophinae}

Key to tribes.

1. Hind corbel semienclosed. Prementum and postmentum lying nearly on the same plane. Alophini

$1^{\prime}$. Hind corbel opened. Prementum and postmentum not lying on the same plane, prementum a little retracted inwards.

Byrsopagini

Tribe Alophini

Trichalophus Leconte

Tribe Byrsopagini

Byrsopages Schönherr

Subfamily Smicronychinae

Smicronyx Schönherr

\section{Subfamily Anthonominae}

Key to tribes.

1. Hind corbel semienclosed, uncinate, the uncus arisen from the lower part of the inner carina .......................................2

$1^{\prime}$. Hind corbel opened, mucronate or unarmed ..........................

2. Antennae with funicle 6-segmented. Body elongate, elytra subparallel-sided. Rostrum nearly as long as head and pronotum taken together

Bradybatini

2 '. Antennae with funicle 7 -segmented. Body pear-shaped, strongly convex. Elytra with tubercles. Rostrum longer than head and pronotum taken together Tachypterellini

3. Body slender, parallel-sided. Mucro of front tibia small.

Brachyonychini

3'. Body pear-shaped. Mucro of front tibia sickle-shaped

Anthonomini

Tribe Bradybatini

Baadybalus Germar 
Tribe Tachypterellini

Tachypterellus Fall \& Cocker

Tribe Brachyonychini

Euphyllobiomorphus Morimoto

Tribe Anthonomini

Key to genera.

1. Claws free, not appendiculate. Body glossy

$1^{\prime}$. Claws appendiculate or bifid

Anthonomorphus Weise

Subfamily Hyperinae

Key to tribes.

1. Rostrum robust, shorter than pronotum, subquadrate in cross-section, costate. Pronotum with ocular lobes. Styli of ovipositor absent .Cylindrorrhini

$1^{\prime}$. Rostrum cylindrical, slenderer, not strongly costate. .2

2. Front coxae lying at the middle of prosternum. Styli of ovipositor absent. IIyperini

$2^{\prime}$. Front coxae lying behind the middle of prosternum. Ovipositor bearing styli Notarini

\section{Tribe Cylindrorrhini}

Listroderes Schönherr

\section{Tribe Hyperini}

Key to genera.

1. Median tibia mucronate, front and hind tibiac unarmed. Rostrum longer than head and pronotum taken together. Pronotum broadest at the base. Elytra slightly longer than wide, convex. Body subglobular Phaeopholus Roelcfs

$1^{\prime}$. Front and median tibiae mucronate. Rostrum as long as or shorter than head and pronotum taken together. Elytra distinctly longer than wide, shoulders subrectangular Hypera Germar

\section{Tribe Notarini}

\section{Key to genera.}

1. Scutellum small or absent. Elytra with the 1st, 3rd and 5th intervals costate Subtribe Orthocaetina. Caenosilapillus Chûjô et Morimoto

1'. Scutellum present. Elytra not costate ......Subtribe Notarina......2 


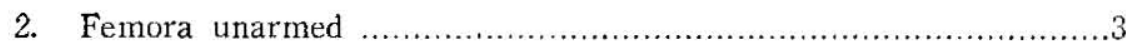

2'. Femora armed each with a small tooth........ Dorytomus Germar

3. Antennal scrobes oblique, directed posteriorly to the lower margin of the base of rostrum. Derm clothed with oval scales. Ocular lobes present ................................. Echinocnemus Schönherr

$3^{\prime}$. Antennal scrobes parallel to the axis of rostrum. Ocular lobes lacked. Derm sparsely clothed with narrow scales .................4

4. Rostrum closely punctured, neither striate nor costate, weakly flattened dorsally Procas Stephens

4'. Rostrum with punctured striae and keels Noturis Stephens

\section{Subfamily Mecyslobinae}

Key to genera.

1. Tibiae mucronate and further uncinate. Frons between eyes deeply depressed Mesalcidodes Voss

$1^{\prime}$. Tibiae uncinate, the uncus arisen from the lower end of the inner carina. Frons flat. Mecyslobus Reitter

\section{Subfamily Carciliinae}

Carcilia Roelofs
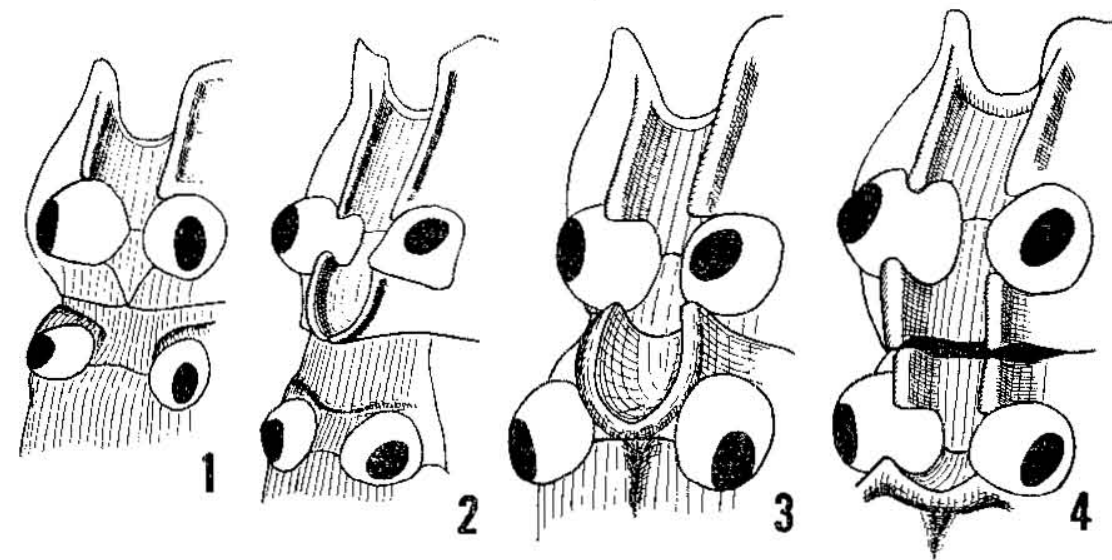

Fig. 1. Pectoral canals of Cryptorrhynchinae.

1. Colobodes ornatus (Ithyporini).

2. Camptorrhinus sp. (Camptorrhinini).

3. Cryftorrhynchus lapathi (Cryptorrhynchini).

4. Mechistocerus nipponicus (Sophrorrhinini).

\section{Subfamily Cryptorrhynchinae}

Key to tribes.

1. Tarsal claws toothed near the base. Pectoral canal not extending 
behind front coxae ......................................Chonotrachelini

$1^{\prime}$. Tarsal claws simple ........................................................2

2. Pectoral canal not extending behind front coxae. Antennal club oval, compact, not annulate or the apical margin of each segment oblique to the axis of club or strongly waved.............. Ithyporini

2 . Pectoral canal extending onto the posterior margin of prosternum

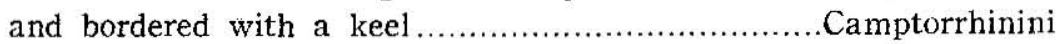

$2^{\prime \prime}$. Pectoral canal extending onto mesosternum .........Cryptorrhynchini

$2^{\prime \prime}$. Pectoral canal extending onto metasternum ............Sophrorrhinini

\section{Tribe Chonotrachelini}

Catagmatus Roelofs

\section{Tribe Ithyporini}

\section{Key to genera.}

1. Antennal scrobes closely approximate to each other under the base of rostrum. Front coxae slightly separated

Ectatorhinus Lacordaire

$1^{\prime}$. Antennal scrobes broadly separated throughout their length $\ldots . . .2$

2. Wings vestigial. Elytra with humeri absent. Abdominal process as broad as metacoxa.

2 '. Wings normal. Elytra with humeri rectangular, parallel-sided...... Colobodes Schönherr

3. Front coxae contiguous ..................................................

$3^{\prime}$. Front coxae separated. Elytra tuberculate......Acallinus Morimoto

4. Femora unarmed. Ocular lobes of pronotum absent. Antennal club compact, oval. Prosternum slightly grooved before coxae Protacallinus Morimoto

4'. Femora armed with tooth. Ocular lobes developed. Antennal club oblong-oval. Prosternum deeply canaliculate before coxae.

Protacalles Voss

\section{Tribe Camptorrhinini}

Camptorrhinus Schönherr

\section{Tribe Cryptorrhynchini}

Key to subtribes.

1. Metasternum separated from the 1st visible segment of abdomen between coxae and metepisterna. Abdominal process between coxae narrower than coxa. Metepisterna distinct 
$1^{\prime}$. Metasternum contiguous to the 1 st visible segment of abdomen between coxae and metepisterna. Metepisterna narrow or vestigial. Metasternum very short

Subtribe Tylodina

\section{Subtribe Cryptorrhynchina}

1. Second visible segment of abdomen longer than the 3rd ...........2

$1^{\prime}$. Second visible segment of abdomen as long as the $3 \mathrm{rd} \ldots \ldots \ldots \ldots . . .7$

2. Femora sulcate beneath..................................................... 5

$2^{\prime}$. Femora not sulcate beneath ...........................................

3. Apex of elytra separately rounded. Rostrum curved. Second visible segment of abdomen as long as the 3rd and 4th taken together...

Heterocryptorrhynchus Morimoto

$3^{\prime}$. Conjoint apices of elytra acuminate posteriorly...................4

4. Apex of elytra less pointed. Rostrum cylindrical, straight ......... Cechania Pascoe

4'. Apex of elytra distinctly pointed. Rostrum curved, not cylindrical. Syrotelus Pascoe

5. Second visible segment of abdomen shorter than the 3rd and 4th taken together. Frons depressed on each side above eyes. Body rhombic Rhyssematoides Morimoto

$5^{\prime}$. Second visible segment of abdomen as long as the 3rd and 4th taken together (2) . 
than the level of vertex

11. Femora distinctly sulcate beneath in entire length. Tibiae with the inner carina of corbels not laminate,... Shirahoshizo Morimoto

$11^{\prime}$. Femora not distinctly sulcate. Tibiae with the inner carina of corbels strongly laminate Paracryptorrhynchus Morimoto

12. Rostrum separated from frons by a transverse shallow depression, frons above the depression with a median short keel. Femora armed each with a tooth .................Sculptosternellum Morimoto

12'. Rostrum contiguous with frons. Femora and tibiae grooved throughout. Femora each armed with two teeth. Receptacle with the posterior part of the border narrower than the lateral part... Coelosteridius Morimoto

\section{Subtribe Tylodina \\ Key to genera.}

1. Metepisterna invisible. Femora not sulcated beneath. Derm clothed with setae and amorphous incrustation. Small species ... Microcryptorrhynchus Lea

1'. Metepisterna distinctly visible. Femora sulcate beneath ...........2

2. Elytron with 9 striae. Receptacle strongly prominent and the posterior margin costate. Second segment of abdomen Ionger than the 3rd and 4th taken together. Scutellum absent

Pseudoporopterus Lea

2 '. Elyton with 10 striae. Receptacle not strongly prominent, with a pair of fovea on the bottom. Second segment of abdomen shorter than the $3 \mathrm{rd}$ and 4 th taken together. Scutellum minute

Hyotanzo Morimoto

\section{Tribe Sophrorrhinini}

Key to genera.

I. Antennae with funicle 6-segmented. Femora grooved beneath for nearly their entire length. Second visible segment of abdomen shorter than the 3rd and 4th taken together. Metepisterna visible throughout their length. Pronotum broadest at the base. Body oval, convex. Small species .............. Deiradocranoides Morimoto

$1^{\prime}$. Antennae with funicle 7 -segmented ...................................2

2. Metepisterna concealed. Femora not grooved. Derm clothed with setae, scales and amorphous incrustation. Small species

Catabonops Roelofs

$2^{\prime}$. Metepisterna distinctly visible.

3. First suture between 1 st and 2nd visible segments of abdomen deeply depressed on each side and weak or obsolescent at the 
middle, especially in male. Frons with a deep fovea between eyes. Femora more or less clavate. Abdominal process between coxae narrower ...4

3 . First suture of abdomen distinct throughout its length in both sexes. Abdominal process broader. Femora nearly of the same width throughout their length, sublinear, not clavate

Rhadinomerus Faust

4. Front femora uniformly clothed with scales. Abdominal process as broad as the base of femur. Front femora not much exceeding from the anterior margin of head. Body parallel-sided. Pronotum very strongly punctured ..........................................Monaulax

$4^{\prime}$. Dorsal area of the base of femora not scaled, glossy. Abdominal process broader than the base of femur. Front femora much exceeding anteriorly from head Mechistocerus Fauval

\section{Subfamily Acicneminae}

Key to genera.

1. Scutellum concealed. Metasternum contiguous with the 1 st visible segment of abdomen between coxae and metepisterna. Humeral callus obsolescent Metrachodes Marshall

$1^{\prime}$. Scutellum distinct, often small. Metasternum separated from the 1st visible scgment of abdomen between coxae and metepisterna

2. Hind femora unarmed..................................................... 3

2 '. Hind femora armed each with a triangular tooth

Acicnemis Lacordaire

3. Antennal scrobes separated throughout. Scutellum small, transverse, glossy. Prosternum before coxae flat. Pronotum convex. Elytra broadest at the middle, convex .........Atrachodes Morimoto

3'. Antennal scrobes confluent under the base of rostrum. Scutellum oval, scaled. Pronotum before coxae depressed. Pronotum with three longitudinal depression. Elytra parallel-sided Karekizo Morimoto

\section{Subfamily Pissodinae \\ Key to tribes.}

1. Abdominal process between hind coxae subtruncate, nearly as broad as coxa. Rostrum a little shorter than pronotum. Eyes closely approximated to or partly concealed by the anterior margin of pronotum Cotasteromimini

1'. Abdominal process much narrower than coxa. Rostrum slenderer, cylindrical. Temples of head as broad as the diameter of eye ... Pissodini 


\section{Tribe Cotasteromimini}

Key to genera.

1. Rostrum contiguous with frons. First segment of funicle robust, 2nd segment deeply retracted into the 1st. Derm clothed with erect scales and amorphous incrustation

Pseudohylobius Morimoto

1'. Rostrum separated from frons by a transverse depression. Funicle normal. Derm clothed with depressed scales and incrustation Cotasteromimus Chûjô et Voss

\section{Tribe Pissodini}

Pissodes Germar

\section{Subfamily Cleoninae}

Key to tribes.

1. Rostrum robust, costate, subquadrate in cross-section. Second segment of hind tarsi as long as or longer than the 3rd

Cleonini

1'. Rostrum cylindrical, not or weakly costate. Second segment of hind tarsi shorter than the 3rd Lixini

\section{Tribe Cleonini}

Key to genera.

1. Inner margin of front tibia serrate. First segment of funicle longer than the 2nd

$1^{\prime}$. Inner margin of tibiae not serrate. First segment of funicle as long as the 2nd Nemoxenus Faust

2. Median keel of rostrum distinctly striate .........Cleonus Schönherr

$2^{\prime}$. Median keel of rostrum not striate Adosomus Faust

\section{Tribe Lixini}

Key to genera.

1. Body cylindrical. Pronotum longer Lixus Fabricjus

1'. Body oval. Pronotum broader, the sides strongly rounded Larinus Germar

\section{Subfamily Galloisiinae} Galloisia Hustache

\section{Subfamily Trigonocolinae}

Trigonocolus Lacordaire 
Subfamily Magdalinae

Magdalis Germar

Subfamily Tanysphyrinae

Tanyshyrus Schönherr

\section{Subfamily Hylobiinae}

Key to tribes.

1. Terminal segment of tarsus with its inferior apical margin produced into a stout tooth beneath each claw; mentum sinuate or deeply bifurcate at apex Paipalesomini

$1^{\prime}$. Terminal segment of tarsus simple at apex; mentum simple......2

2. Prosternum not excavated .................................................. 3

$2^{\prime}$. Prosternum excavated ............................................. Lithinini

3. Abdominal process between hind coxae acuminate or ogival, much narrower than a hind coxa; hind coxae transversely elongate ...4

3'. Abdominal process between hind coxae nearly as broad as or broader than a hind coxa; hind coxae more or less subglobular Anchonini

4. Elytra with a distinct humeral callus........................... Hylobiini

$4^{\prime}$. Elytra without a humeral callus; wings rudimentary ....... Liparini

Tribe Paipalesomini

Peribleptus Schönherr

\section{Tribe Lithinini}

Key to genera.

1. Rostrum robust, contiguous with frons. Abdominal process between hind coxae narrower than coxa. Claws appendiculate.

Niphades Pascoe

1'. Rostrum slenderer, separated from frons by a transverse depression. Abdominal process broader than hind coxa .............2

2. Frons between eyes half as broad as the base of rostrum. Last punctured stria of elytra ending above hind coxa

Nipponiphades Kôno

$2^{\prime}$. Frons between eyes as broad as the base of rostrum. Last punctured stria of elytra not shortened.

Seleucha Pascoe

\section{Tribe Hylobiini}

Key to genera.

1. Antennal club visibly two-segmented Aclees Schönherr 


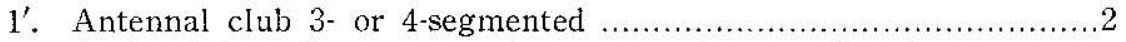

2. Ocular Iobes of pronotum absent, anterior margin of prosternum

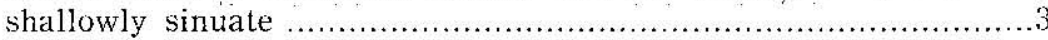

$2^{\prime}$. Ocular lobes present, anterior margin of prosternum deeply excavate ......................................................................

3. Eyes lateral ..............................................epyrus Schönherr

3'. Eyes approximate to each other under head .........Hybolius chujô

4. Hind wings functional, normal ...................................... 5

$4^{\prime}$. Hind wings vestigial, not functional ................................. 6

5. Frons between eyes as broad as the base of rostrum. Rostrum straight......................................................... Kobuzo Kôno

$5^{\prime}$. Frons between eyes narrower than the base of rostrum. Rostrum more or less curved.......................................Hylobius Germar

6. First and 5th visible segments of abdomen each with a pair of setal tufts.............................................. Okikuruminus Kôno

$6^{\prime}$. Abdomen without special setae .........................Poiyaunbus Kôno

Tribe Anchonini

Olibazo Morimoto

Tribe Liparini

Key to genera.

3. Scutellum concealed

Euthycus Prscoe

$1^{\prime}$. Scutellum small, triangular.............................. Liparus Olivier

Subfamily Bagoinae

Bagous Germar

\section{Family Rhynchophoridae \\ Key to subfamilies.}

1. Front coxae separated. Pygidium often exposed

$1^{\prime}$. Front coxae connate. Pygidium concealed. Tarsi visibly 4-seg-

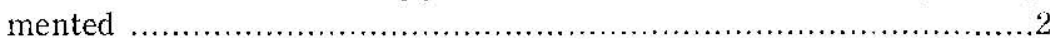

2. Third tarsal segment bilobed, much broader than the 2nd. Antennae not geniculate, inserted into the base of rostrum, antennal scrobes oval Cryptoderminae

2.' Third tarsal segment as broad as the 2nd. Antennac geniculate, inserted a little before the base of rostrum, antennal scrobes normal Orthognathinae

3. Pygidium exposed. Tarsi visibly 4-segmented. Antennal funicle 6-segmented Rhynchophorinae

3'. Pygiclium concelaed. Tarsi 5-segmented. Antennal funicle 4-segmented..... Dryophthorinae 
Subfamily Cryptoderminae

Cryptoderma Ritsema

\section{Subfamily Orthognathinae}

Key to tribes.

1. Prothorax without ocular lobes. Antennal club with the tomentose part developed Orthognathini

1'. Prothorax without ocular lobes. Antennal club with the tomentose part flat.... Stromboscerini

\section{Tribe Orthognathini}

Hyposipalus Voss

\section{Tribe Stromboscerini}

Key to genera.

1. Antennal funicle 6-segmented Orthosinus Motschulsky

$1^{\prime}$. Antennal funicle 5-segmented Synommatus Wollaston

$1^{\prime \prime}$. Antennal funicle 4-segmented Dryophthoroides Roelofs

Subfamily Dryophthorinae

Dryophthorus Schônherr

\section{Subfamily Rhynchophorinae}

Key to tribes.

1. Mesepimera smaller than mesepisterna. Antennal club oval, not depressed Sitophilini

1'. Mesepimera larger than mesepisterna. Antennal club often flattened Rhynchophorini

\section{Tribe Rhynchophorini}

Key to genera.

1. Metepisterna very broad, parallel-sided, about three times as long as wide. Prosternal process undivided...Subtribe Rhynchophorina Otidognathus Lacordaire

$1^{\prime}$. Metepisterna narrow, broadest at the anterior margin. Prosternal process subdivided into sternellum and basisternum by a suture Subtribe Sphenocoryna...............................2

2. Third segment of tarsi as broad as the 2nd. Antennal club not depressed, scape as long as funicle Cosmopolites Chevrolat 
2 '. Third segment of tarsi much broader than the 2nd. Antennal club more or less depressed.............................................. 3

3. Femora dentate. Rostrum much shorter than pronotum............... Sphenocorynus Schönherr

$3^{\prime}$. Femora unarmed. Rostrum nearly as long as pronotum

Aplotes Chevrolat

\section{Tribe Sitophilini \\ Key to genera.}

1. Hind femora reaching beyond the apex of elytra. Frons between the dorso-posterior ends of eyes with an arched keel

Paracalendra Châjô et Morimoto

$1^{\prime}$. Hind femora at most reaching the apex of elytra. Frons without

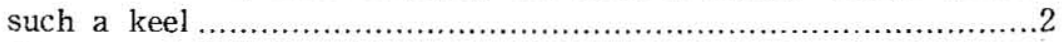

2. Derm not clothed with setae. First and 2nd segments of abdomen conglutinate together......................................... Polytus Faust

2 . Derm clothed with short erect setae .................................... 3

3. First and 2nd segments of abdomen fused at the middle ...........

3'. First and 2nd segments of abdomen separated by a distinct suture. Sitophilus Schönherr 